\title{
Cronologia do Horror
}

Marco Antonio Coutinho Jorge 1

\section{Resumo}

Cronologia do horror é a reunião de vários escritos, nunca publicados antes, feitos ao longo dos últimos anos a partir de eventos ocorridos no mundo e, em especial, em nosso país. Transmitem a necessidade de colocar palavras no horror quando este, apresentando-se nu e cru, dilacera nossa alma com uma dor insuportável.

PALAVRAS-ChaVe: Horror; real; trauma; angústia; dor; simbolização.

1 Médico, psiquiatra, psicanalista, diretor do Corpo Freudiano Seção Rio de Janeiro. Autor da série Fundamentos da psicanálise - v.1: as bases conceituais; v.2: a clínica da fantasia; v.3: a prática analítica (publicados); v.4: o laboratório do psicanalista (no prelo). Coautor, com Natália Pereira Travassos, de Transexualidade: o corpo entre o sujeito e a ciência. Todos publicados pela editora Zahar. 
Essa cronologia do horror reúne textos breves escritos ao longo dos últimos quatorze anos, todos inéditos, exceto $A$ celebração da lei, publicado no caderno "Eu e Fim de semana" do jornal Valor Econômico.2 Foram escritos no rastro do impacto produzido por eventos violentos ocorridos no Rio de Janeiro, no Brasil e no mundo. Encontram agora a ocasião para virem à luz, no ano do IX Encontro Nacional e IX Colóquio Internacional do Corpo Freudiano sobre $O$ mundo e o imundo: a psicanálise diante do horror.

\section{5: Perguntas Sem Resposta}

Estamos às vésperas do Natal de 2005 e nos perguntamos: como é possível comemorar o nascimento do menino Jesus, Cristo redentor, quando várias pessoas são feridas gravemente ou mortas, entre as quais um bebê, carbonizado, nos braços de sua jovem mãe, num ataque contra simples trabalhadores promovido por bandidos com o intuito de - para nosso estupor - se vingar da polícia pela morte de um traficante? Quem nos relata os detalhes, sem culpa ou remorso, é esta adolescente de treze anos, que comandou a façanha cujo objetivo era matar, queimando-os vivos, todos os passageiros. Quem é essa jovem e seus comparsas que parecem sair da pré-história para conviver com a humanidade?

Por que essa bebezinha, chamada Vitória Cristina Barbosa de Oliveira, não pôde viver mais do que um ano e foi arrancada da vida tão cedo por um tenebroso acaso que lhe lançou subitamente à barbárie da qual não tinha qualquer meio para se defender? Por que sua mãe, Wânia Lúcia Barbosa, não pôde - como Maria, cuidar e amar aquele que seria o salvador - proteger seu bebê e a si mesma da violência que irrompeu como que vinda subitamente do inferno e transformou seu colo caloroso numa chama incandescente? Por que mãe e filha, morreram juntas, indefesas, sem qualquer motivo, sem qualquer causa, sem qualquer misericórdia?

Como poderá viver daqui para frente esse pai, Rogério Mendes de Oliveira, que, desesperado, viu tudo e não pôde fazer o que um pai faz, defender sua mulher e a sua prole? Que tamanha dor é essa que ele sente agora e que podemos apenas

2JORGE, M. A. C. (2006). Efusiva e exemplar celebração da lei. Valor Econômico, Rio de Janeiro, ano 6, n. 299, 16, 17 e 18 de jun. 2006. "Caderno Eu \& fim de semana", p. 13. 
pressentir em nossa condição de espectadores atônitos, embora tão desesperados quanto ele, ainda que não tenhamos perdido nossa mulher e nosso bebê, mas, sim, nossa esperança?

A pior dor é a perda da esperança de que possamos vislumbrar um mundo melhor para os brasileiros. Ela queima como o fogo do ônibus 350 e nos retira toda a alegria de que seríamos capazes caso não tivéssemos tido nossa alma devastada por este e outros episódios. Nesse Natal de 2005, sentimos horror, tristeza profunda, desamparo, angústia avassaladora, total desesperança. Sentimos, de uma só vez, todos os sentimentos mais dolorosos de que somos capazes em nossa humanidade. Não temos qualquer motivo para comemorar.

No entanto, a cidade está preocupada com o seu embelezamento. A árvore de Natal implantada anualmente dentro das águas da Lagoa Rodrigo de Freitas, cada vez maior, mais bela, mais rica e feérica, atrai multidões para verem seu complexo espetáculo diário, agora acompanhado por um chafariz sincronizado com luzes. Os prédios são delicadamente iluminados de forma ornamental e concorrem a prêmios organizados pela Prefeitura. As árvores são enlaçadas por minúsculas lâmpadas que dão mais vida a seus troncos. A beleza parece invadir todos os espaços.

Mas o que falta à nossa cidade não é beleza, pois isso ela esbanja. Ela não necessita de qualquer adorno. Suas árvores naturais - as que restam da devastação da Mata Atlântica - já são únicas e perfeitas. A Lagoa - apesar do descuido a que é submetida como, de resto, toda a cidade - é, por si mesma e sem qualquer adereço, um espetáculo deslumbrante para os olhos. Em nossa cidade dita com razão maravilhosa, a beleza é tão comum! Por que querer mais beleza então? Por que tantos enfeites? Será que eles vêm encobrir o que de fato nos falta?

Embora Cristo mantenha seus braços abertos lá no alto do Corcovado, num gesto simples, mas profundamente simbólico, concebido pelo escultor brasileiro Heitor da Silva Costa, que consegue transfigurar a dor da crucificação na comunhão do amor, aqui na cidade, nós, cidadãos, seguimos a Via Crúcis diariamente. Quando esse gesto será convertido em realidade?

A desesperança é, no fundo, política. Quando será possível termos uma democracia em que a participação dos eleitores não se limite a emitir um voto num dia, para depois sofrer calados quatro anos seguidos? Será possível um dia termos uma democracia na qual seja possível julgar os governantes, quando eles faltarem 


\section{Cronologia Do Horror}

com as obrigações a que se candidataram, condenando-os a duras penas pela falta de amor pelo seu povo? Quando será possível termos, no lugar desses governantes, pessoas que compartilham de nossa humanidade e não visam apenas seus próprios lucros e interesses imediatos, para que cuidem da população de modo a evitar que nela se desenvolva, como um câncer incontrolável, a fúria assassina que pode facilmente se apossar de uma criança, transformando-a num bárbaro sanguinário, quando ela não tem condições mínimas de amor e de dignidade para viver e sobreviver? Quando acontecerá que uma preocupação humana verdadeira tome posse nos planaltos e nos palácios de governo em nossa cidade e em nosso país, honrando de fato um povo que insiste em afirmar diariamente que Deus é brasileiro?

São essas perguntas sem resposta, entre muitas outras, que nos vêm nesse tristíssimo Natal carioca de 2005.

\section{5: O Que Votaremos Realmente em 23 de Outubro?}

Diante da verdadeira pletora de manifestações a favor do voto "Sim", seguida pouco depois por outras numerosas manifestações a favor do "Não", no dia 23 de outubro próximo no referendo sobre a proibição da comercialização de armas de fogo e munições no território nacional, cabe perguntarmos com honestidade: o que votaremos de fato nesse dia?

Pergunta cuja resposta pode decidir uma certa posição a defender por cada um de nós. Eu, que não tenho qualquer dúvida sobre a necessidade de votar "Sim", parei para me perguntar por que pessoas que acredito que pensam como eu defendem o "Não".

Estaremos votando - desejando, pois o voto é antes de mais nada, aspiração, desejo - a favor da vida, pura e simplesmente? Não seria de surpreender, pois este é um argumento que vai direto ao ponto: esta invenção humana chamada não sem motivos de "arma-de-fogo" é absolutamente hedionda e que seres pacíficos e civilizados não conseguem entender o porquê de sua existência na face da Terra. A arma de fogo é a materialização da covardia, com ela o homem adquire um poder que ele não tem. Armado, esbanja onipotência e, covarde, distribui impotência e humilhação - quando não morte.

Todos os que, como eu, defendem que se responda "Sim" argumentam de uma maneira tal que somos levados a concluir que "é claro que só há uma resposta possível: somos radicalmente contra o favorecimento do crime passional, do acidente 
com armas de fogo, da perda estúpida de vidas, do aumento da banalização da violência, já tão espraiada na sociedade".

O estranho é que alguns de nós vamos votar "Sim" pelos mesmos motivos que alguns de nós - não todos - seremos levados a votar "Não": todos nós queremos algo que não se viabilizará de modo algum com esta votação. Pois o que vamos de fato votar é que queremos poder sentir um mínimo de segurança nas ruas e em nossas casas, sem que uma bala dita "perdida" nos atinja ou a alguém que amamos. Sem que sejamos assaltados por traficantes nos famosos "bondes" ou em falsas blitze. Queremos poder ter uma vida na qual a arma de fogo não seja estampada na nossa cara a cada dia - senão a cada momento - e a possibilidade da morte se torne tão corriqueira que seja preciso que andemos armados até os dentes. O sim e o não raramente estiveram a favor das mesmas coisas como nesse caso.

\section{6: A CelebraçÃo da LeI}

O que é o futebol? Tal pergunta, colocada nas vésperas da Copa do Mundo em que o Brasil aspira ao hexacampeonato, parece sem sentido. Contudo, assim como Roberto DaMatta já mencionou, no campo da sociologia, o "mistério" do futebol, para a psicanálise há nessa interrogação um grande enigma que pede investigação: o futebol é um poderoso fenômeno de massa.

Pois a cada semana, em todas as partes do mundo, milhares de pessoas, na grande maioria homens, se comprimem em estádios, muitos verdadeiramente faraônicos, construídos exclusivamente para esse fim, para torcer por seus times e, mais esporadicamente - mas também com maior intensidade -, por seu país. O som produzido nos estádios, de uma qualidade inigualável pelo de qualquer outro conglomerado humano, pode ser ouvido à distância. Em absoluto uníssono, urros, gritos, exclamações, imprecações são produzidas pelos torcedores de modo absolutamente surpreendente, colocando questões fundamentais: o que é, de fato, o futebol? O que ele coloca em cena? O que ele mobiliza? Para a psicanálise, a questão é, no fundo: de onde vem a força desse esporte para reunir multidões, arrancar tantas emoções e despertar tanta fala entre os sujeitos? De onde vem essa violenta paixão?

Algumas coisas do futebol já sabemos com a psicanálise. Sabemos que o esporte, em geral, proporciona uma intensa forma de satisfação, ao colocar em atividade o aparelho motor e oferecer-lhe condições ótimas para descarregar a 


\section{Cronologia Do Horror}

agressividade. Dito de outro modo, a agressividade é inerente a todo esporte e pode ser bem evidenciada no futebol ao estudarmos a sua linguagem, francamente bélica: ataque e defesa, capitão, artilheiro, tática, barreira, etc. Cada jogo é a representação alegórica da guerra. $O$ amor e a guerra são o sal da terra, já dizia o poeta.

O time é um miniexército que visa a conquista da vitória. Fala-se de tiro de meta, petardo e canhão (para designar chutes poderosos), de poder de fogo do time etc. Os exemplos são intermináveis e a linguagem futebolística evidencia, com todas as letras, que, inconscientemente, nesse esporte, a guerra comparece velada, traduzida nas exigências da cultura humana. Há alguns anos, a figura da morte, que jamais comparecerá no jogo, se tornou presente, enfim, com a nova regra da "morte súbita". Mas ela durou pouco tempo. Tudo indica que a "morte súbita" escancarou demais os desígnios destrutivos inconscientes inerentes ao futebol. Ela foi substituída pelo "gol de ouro".

O jogo de futebol constitui, de fato, a sublimação das forças (chamadas pela psicanálise de pulsões) de dominação e agressão inerentes ao humano, e as coloca em cena sob uma forma civilizada, passível de ser admitida para que haja convívio entre indivíduos, assim como entre povos. Tal afirmação encontra sua confirmação na manifestação oposta - infelizmente cada vez menos episódica - dos fenômenos de violência entre torcidas, dos quais os hooligans ingleses constituem o bárbaro paradigma, e entre jogadores. Pois a sublimação das pulsões agressivas e sexuais não pode ser total (este é um dos axiomas da psicanálise), elas exigem sempre uma parcela de realização direta corporal de satisfação.

Mas temos uma hipótese que vai um pouco mais longe. Segundo ela, o futebol é, no fundo, a celebração da vigência da Lei humana. É o juiz que, entre os jogadores, conduz a partida e as possibilidades que esta apresenta; é ele quem, invisível (ninguém olha para ele), sem tocar na bola (ele a evita), dá a ela todo seu sentido (inicia e encerra o jogo, o interrompe se achar necessário, valida ou não o gol) e emoldura o quadro no interior do qual todo o jogo se desenrolará. É com referência a ele - presença materializada da Lei em campo, com sua austeridade, seu apito e cartões amarelos e vermelhos -, que os homens se conduzem para conquistar a vitória. A vitória é buscada, mas deve ser obtida dentro da Lei.

Não seria essa efusiva celebração da Lei o que faz com que o futebol encontre no Brasil sua máxima expressão? Num país onde a Lei, em suas mais diferentes dimensões, parece redundar eternamente em fracasso, os homens bons parecem 
denunciá-lo ao encontrar no futebol o espaço para celebrá-la em toda sua plenitude e vigor.

Isso pode ser uma fecunda indicação para nossos (poucos) políticos que almejam bem-estar social verdadeiro: criar projetos que mobilizem pelo menos parte da enorme energia posta em ação com tanto entusiasmo - quando se trata do jogo de futebol, pelos jogadores, times, torcidas - no sentido de ações coletivas urgentes. Pois eles, ao celebrarem periodicamente a Lei nos jogos, demonstram que sabem, ainda que inconscientemente, até onde se pode ir para se conseguir o que se deseja. $E$ isto é a essência da Lei humana. $E$, por enquanto, algo que no Brasil é raro, a não ser nos domínios desse belo e exemplar esporte.

O poder Legislativo, ao fazer as leis, os juízes, ao aplicarem-na, os promotores, ao fiscalizarem a sua aplicação e os advogados, ao defenderem os sujeitos, deveriam igualmente tomar este exemplo do povo brasileiro e aprender com ele a celebrar a Lei cotidianamente.

Conforme nos mostraram Freud e Lacan, a língua nos ensina muito sobre o que se passa no inconsciente. Um país no qual a palavra legal, segundo o Dicionário Houaiss, além de algo relativo à lei do âmbito propriamente jurídico, tem um uso informal que "qualifica pessoas ou coisas com atributos positivos: belo, bom, amável, compreensivo, interessante, curioso, justo", apresenta problemas evidentes com a lei. Sem substância real no cotidiano, resta à lei ser um adjetivo de uso coloquial, invocado por cada cidadão algumas dezenas de vezes por dia. Inexistente enquanto força social a ser entronizada coletivamente, a lei é pulverizada na fala de cada um como uma constante e impossível aspiração.

\section{7: UMA MORTE EMBLEMÁtICA}

Dou-me conta de que as três histórias mais terríveis de que tenho notícia envolvem todas elas a morte de uma criança. Uma, narrada com estupefação por um amigo, Alain Didier-Weill, que tinha acabado de voltar de uma viagem à Índia, é aquela da criança pequena que, numa certa localidade, foi arrancada de um passeio de mãos dadas com os pais por uma águia e levada embora para sempre. A angústia dos pais, a consternação e o luto do vilarejo onde isso ocorreu eram indescritíveis.

Outra, narrada por Elie Wiesel em seu livro Night, sobre o dia em que um menino - um "anjo de olhos tristes" -, foi enforcado pela Gestapo, em Auschwitz, 


\section{Cronologia Do Horror}

diante do olhar dos milhares de prisioneiros, obrigados a presenciar sua morte. Wiesel conta que à pergunta por todos colocada "Onde está Deus agora?", ele respondera em seu íntimo: "Aí está Ele - ali, pendurado naquele patíbulo". Executar friamente um inocente significa matar a própria inocência.

A terceira, foi a morte do menino João Hélio Fernandes, arrastado por um carro dirigido por adolescentes no Rio Janeiro. Das três, a que mais me horroriza é a última, porque ocorreu neste início de 2007 e na mesma cidade em que eu vivo. E também porque se trata de uma morte emblemática.

Fui à Missa de Sétimo dia do menino morto barbaramente. Foi a maneira que encontrei de aliviar um pouco a insuportável dor que sentia pela tragédia. Um amigo que foi comigo levou a bandeira do Brasil que guardava desde a Copa do Mundo e lá entregamos a bandeira aos pais e irmã de João Hélio e dissemos a eles que guardassem esta bandeira para sempre, pois ela simbolizava a dor que o país inteiro sentia. Era preciso dizer alguma coisa, fazer algo, dar a mão a eles.

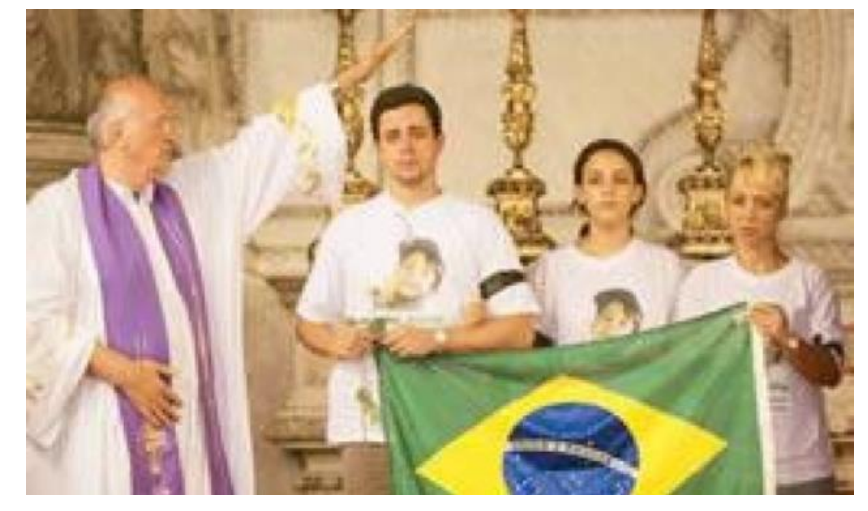

Dentro da Igreja da Candelária, fiquei de pé na frente, próximo à família do menino mártir e pude ver de frente a comoção estampada no rosto das pessoas. Muitas vestiam camisetas com fotos e nomes de muitos outros jovens e crianças mortos em situações semelhantes, igualmente vítimas da violência descontrolada que acomete a cidade. A multidão urrava de vez em quando "Justiça?', "João?'. A maioria chorava. Muitos se aproximavam e abraçavam os membros da família, dispostos na primeira fila. O Governador Sérgio Cabral entrou antecedido por um forte corpo de segurança. Foi fortemente vaiado ao ter anunciada a sua presença. Fez uma rápida declaração e se retirou, não permanecendo para a missa. Surpreendeu-me a presença escassa de pessoas na missa e na passeata que se seguiu, da Igreja até a Cinelândia. A Igreja estava lotada, é fato, mas eu esperava muito mais gente, imaginava que a cidade estivesse inteiramente congestionada e que uma multidão 
fechasse todas as ruas de acesso à Avenida Presidente Vargas. Afinal, a gravidade do fato pedia isso. Na passeata, as centenas de pessoas que saíram da lgreja e entraram na Avenida Rio Branco entoavam os mais diferentes gritos: "So-cor-ro!', "Jus-ti-ça?", "Senhor Governador, chega de horror?".

O grito que mais me emocionou foi: "Não vai ser em vão a morte do João?". Mas as pessoas gritavam também chamando para participar da manifestação as outras que, nas calçadas, olhavam o desfile como se fosse algo que não tivesse a ver com elas. Os membros da passeata gritavam e acenavam para os transeuntes, gesticulando com os braços chamando-os a participar: "Você aí parado, também é assaltado!". Paradas, as pessoas observavam com um misto de receio e de curiosidade. Inquietante a sensação de que a maioria aparentava nem mesmo saber do que se tratava. Ninguém aderia ao cortejo inflamado, fazendo-nos diagnosticar na população carioca um quadro agudo de ataraxia. A passeata vociferava às vezes: "Cadê os cariocas?".

A morte emblemática de João nos faz pensar sobre muita coisa. Na missa, intuindo o ódio que se insinuou rapidamente no coração da multidão, os padres enfatizaram a necessidade de não combater a violência com violência e apelaram à justiça divina e proclamaram o amor. A palavra paz foi enunciada dezenas de vezes. Ela é o lema ao qual se agarram todos, mostrando que nessa hora é preciso arranjar um poderoso dique para conter nosso ódio. Devastada pela dor, a irmã de João Hélio disse, contudo: "Para estes criminosos a pena de morte é pouco".

A morte de João Hélio nos faz, em contrapartida, pensar igualmente sobre o valor da vida. O caráter sagrado da vida. Não é à toa que o primeiro mandamento enuncia: "Não matarás". Pois sendo a morte irreversível, matar é eliminar a diferença do outro de modo radical. Como afirma Lacan, "a dimensão intolerável oferecida à experiência humana, não é a experiência da própria morte, que ninguém tem, mas a morte de um outro".3

O que espanta nos debates que se seguiram à chacina do menino é a preocupação que parece incidir somente sobre os bandidos; mas será que alguém consegue imaginar o que sentiu João Hélio ao ser arrastado pelo carro até morrer?

3 LACAN, J. Hamlet, Campinas, Escuta/Liubliú, 1986, p.74.

Psicanálise \& Barroco em revista | Edição Especial: Psicanálise e Política: versões e reversões do mundo e do imundo. v.17, n. 02 | outubro de 2019 
A morte de João Hélio é emblemática de uma situação deplorável em que nos encontramos no país: falta de lei e de governo. É um salve-se quem puder: ao serem roubados, mãe e filha saltaram do carro, mas o menino ficou preso ao cinto e foi arrastado. É como estamos todos nós brasileiros nos sentindo: crianças indefesas, arrastadas pela violência e sem chance de nos desvencilharmos dela, esfolados pelo banditismo desenfreado presente em primeiro lugar nos poderes públicos e, como reflexo imediato, na população.

Mas por que, ainda assim, é preciso entender que, quando aquele que nos fez mal nos suscita ódio, responder com violência a ele não é adequado? A resposta da psicanálise não é pela via do amor universal tornado obrigatório, mas, sim, pelo simples fato de que a vingança não permitirá que a irreversibilidade do ato cometido seja desfeita: condenar $\mathrm{o}$ assassino à morte não trará à vida aquele que amamos $\mathrm{e}$ que de nós foi arrancado brutalmente. Isso por si só barra nossa sede de violência e nos traz de volta imediatamente ao nosso insuportável sofrimento: quer dizer que nada poderá aliviar a nossa dor?

É isso que mais horroriza nesse e nos outros episódios de crimes que estamos vivendo no Rio. A impossibilidade de que o menino João Hélio volte a sua vida e tenha, como nós tivemos, a possibilidade de desfrutar das outras etapas da existência humana. Ele não conheceu a adolescência com seus medos e ousadias, não conheceu as dificuldades e as angústias ligadas à escolha profissional e à vida adulta; não viveu a paixão amorosa e seus abismos insondáveis. Sua vida limitou-se àquele breve salto do peixe no mar que, por alguns átimos de segundo, vê a vastidão do mundo, mas rapidamente retorna a ele. Sua vida foi excessivamente breve e ele não teve a chance de poder nos ensinar aquilo que todo sujeito tem, no fundo, para nos ensinar sobre seu mundo interior.

\section{0: Psicopatia na Política Cotidiana? 4}

Recentemente, fortes chuvas trouxeram mais que o caos para o Rio de Janeiro. Além do horror do transbordamento das águas, irrompeu a indignação com o descaso do poder público que permitiu que casas fossem construídas sobre um antigo aterro sanitário, um lixão como costumamos chamar. De lá para cá se descobriu a existência

${ }_{4} \mathrm{~A}$ escrita deste texto contou com a colaboração da psicanalista Julia Cristina Tosto Leite e de um grupo de trabalho do Corpo Freudiano Seção Rio de Janeiro, constituído por Ana Karla Ferreira e Eliana Luiza S. Barros. 
de um total de 18 favelas construídas sobre lixões. Um retrato muito claro foi revelado: no Brasil o povo é tratado como lixo.

Em "O mal-estar na cultura", Freud salienta que um dos propósitos da civilização é proteger os homens contra a natureza. A casa representa para Freud um verdadeiro símbolo do corpo, o abrigo do sujeito; ela é uma metáfora privilegiada, e se enraíza no inconsciente como um substituto do útero materno, o primeiro alojamento pelo qual o homem ainda anseia, onde se achava seguro e se sentia à vontades.

Freud assevera que a palavra cultura descreve a soma das realizações e dos regulamentos que se destinam a garantir a proteção do homem em relação à natureza e o ajustamento de seus relacionamentos mútuos. Mas os anseios do homem com o trabalho da cultura não se restringem ao útil: a beleza, a limpeza e a ordem ocupam um lugar especial entre as exigências esperadas pelo homem. A reverência à beleza se estenderia à natureza, assim como às obras criadas pelo homem. Também não nos surpreende, diz Freud, estabelecer o sabão como "padrão real" da civilização. Finalmente, a ordem, inspirada pelas regularidades dos fenômenos da natureza, introduziria um ritmo, uma repetição que daria limites ao imprevisto, dando origem à utilização do espaço e do tempo. Não deixemos de fora as realizações intelectuais, científicas e artísticas que acrescentariam a busca de prazer como força motivadora das realizações do homem ao lado do objetivo de utilidade.6

O prefeito de Niterói classificou de "desastre natural" as chuvas que caíram no município e, em entrevista no rádio, chegou a afirmar que "ninguém responsabilizou os governantes da Ásia pelo tsunami ou os chilenos pelo terremoto". Afirmando que não sabia que a favela do morro do Bumba estava construída sobre um lixão - embora esteja na prefeitura há 12 anos pessoalmente e 16 indiretamente -, pediu que, "neste momento trágico, não massacrassem nem demonizassem o prefeito". Mas pelo menos dois estudos da Universidade Federal Fluminense já haviam alertado a Prefeitura para os riscos de desabamento. Aprendemos o sentido de uma palavra nova que veio à baila no noticiário: chorume - líquido originado da decomposição de resíduos orgânicos -, que parece associar choro e estrume. 
Embora o uso da mentira na política não seja apanágio do Brasil (vide a invasão do Iraque baseada na divulgação da mentira de que se encontrariam armas de destruição em massa em seu território), a capacidade de mentir de nossos políticos é particularmente surpreendente.

A mentira na política cotidiana talvez seja um bom índice para se verificar o grau de canalhice dos políticos. Numa tirada famosa, um ex-governador de São Paulo, diante de sua assinatura numa conta bancária suíça, disse que ela não era dele. Nossa ministra candidata à presidência fez recentemente um lapso revelador, como todo lapso, da verdade em jogo no inconsciente: ao se referir ao nordestino que vai para Brasília, disse: "Quando ele vai ao Brasil" - ou seja, o Nordeste não é o Brasil. Ou será que Brasília - essa invenção estratégica mas funesta que isolou o poder artificialmente no centro do país - é que não é o Brasil?

Psicopatia é um termo que foi usado, a princípio, como sinônimo de doença mental, sendo que seu uso em sentido mais restrito começa na psiquiatria alemã com Koch (1891), sendo, então, associada com a personalidade e a constituição. Kraepelin, Birnbaum e Gruhle são autores que contribuem para delimitar as fronteiras entre psicopatia e psicose: a primeira seria entendida como uma certa tendência que se manifestaria ou não, dependendo também de fatores ambientais. Kretschmer (1922), ao contrário, estabelece um continuum que vai da normalidade à doença. Progressivamente, a partir da segunda metade do século XX, a importância das influências externas foi sendo privilegiada. "A máscara da sanidade", de 1941, escrito pelo psiquiatra norte-americano Hervey Milton Cleckley, parece ter sido a principal influência para o conceito atual de psicopatia na psiquiatria.

A partir de uma casuística clínica, Cleckley observou que o transtorno fundamental da psicopatia "seria a 'demência semântica', isto é, uma falha na compreensão dos sentimentos humanos em profundidade, embora no nível comportamental o indivíduo aparentasse compreendê-los".7 E por isso ele falou da máscara de sanidade. 8

7 Henriques, Rogério Paes. "De H. Cleckley ao DSM-IV-TR: a evolução do conceito de psicopatia rumo à medicalização da delinquência”. In Rev. Latinoam. Psicopat. Fund., São Paulo, v. 12, n. 2, p. 285302, junho 2009.

8Entre parênteses, ressalto que não cabe aqui fazer um estudo comparativo entre a noção psicanalítica de estrutura perversa e a noção de psicopatia para a psiquiatria. Tal estudo é, contudo, de grande interesse, sobretudo porque ele traz em seu bojo os problemas inerentes à própria noção de perversão em psicanálise. Mas cabe por outro lado manifestar nosso interesse por uma noção que, utilizada para a desqualificação do outro como sujeito (perverso, psicopata) aporta a ambiguidade da necessidade de estabelecer uma compreensão clínica dessa patologia da lei com o rigor das construções teóricas. 
Entre as características destacadas pelo CID-10 para a psicopatia, encontramos no primeiro plano a indiferença insensível pelos sentimentos alheios, assim como a atitude flagrante e persistente de irresponsabilidade e desrespeito por normas, regras e obrigações sociais. Trata-se, portanto, de uma patologia que se poderia denominar de patologia da lei e, por isso, a psicopatia é igualmente chamada de sociopatia. Nesse sentido, tudo indica que o campo político é a região ideal para se verificar essa patologia.

Uma das características mais relevantes que Cleckley reuniu em sua obra sobre a psicopatia (sua descrição da psicopatia como personalidade antissocial personalidade psicopática - vigora até nossos dias, como o atestam as nosografias psiquiátricas contemporâneas) é "a total desconsideração pela verdade; ele não compreende a atitude das pessoas que a valorizam e a cultivam. Tipicamente, ele não se sente constrangido ao mentir, fazendo-o, muitas vezes, de modo mais convincente que uma pessoa que diz a verdade. Quando desmascarado, ele não sente qualquer remorso e só se defende para se desvencilhar de um problema real ou para atingir algum objetivo, nunca para reparar sua reputação".9

Para Freud, o supereu é a instância psíquica que assume, na construção da cultura, o que antes foi do campo da coerção externa. Seria, aliás, através deste agente psíquico que a criança se torna um "ser moral e social". Aqueles em quem esta transformação se realizou seriam veículos e não opositores da cultura. Os neuróticos, no entanto, seriam uma desagradável exceção: obedeceriam às proibições culturais apenas sob a pressão da coerção externa: "Há incontáveis pessoas civilizadas que se recusam a cometer assassinato ou a praticar incesto, mas que não se negam a satisfazer sua avareza, seus impulsos agressivos ou seus desejos sexuais, e que não hesitam em prejudicar outras pessoas por meio da mentira, da fraude e da calúnia, desde que possam permanecer impunes" 10.

A relação entre violência e mentira foi abordada por Jean-Jacques Blévis em sua exposição no colóquio em comemoração aos 60 anos da Declaração dos Direitos do Homem, organizado pelo psicanalista Paolo Lollo na Unesco, em Paris, no final de

\footnotetext{
9 Henriques, Rogério Paes. "De H. Cleckley ao DSM-IV-TR: a evolução do conceito de psicopatia rumo à medicalização da delinquência", op.cit.

10 Freud, S. "O futuro de uma ilusão", p.23.
} 


\section{Cronologia Do Horror}

2008, e do qual eu e Denise Maurano participamos. Chamando atenção para o "vasto programa" que seria estudar o complexo problema da mentira, Blévis ressaltou a importância desse estudo no campo jurídico - "Juro que direi a verdade, toda a verdade, nada mais que a verdade", rege o juramento do direito - e no campo político. Blévis lembra o artigo de Alexandre Koyré "Reflexões sobre a mentira", sobre o uso da mentira na guerra e nas catástrofes, no qual ele chega a afirmar que a mentira é mais própria do homem que o riso.

Por sua vez, considerando que o homem se define pela fala, a psicanálise verifica que há diferentes dimensões da mentira. Em essência, esta relação entre violência e mentira revela, para Blévis, que há mentiras necessárias para evitar a violência, e há mentiras que matam e violentam.

Há mentiras e mentiras. Lacan mostrou como a mentira é uma função subjetiva: indo muito além dos animais, que também sabem fingir, o homem sabe fingir que está fingindo. Freud sublinhou que, para a psicanálise, a palavra mentirosa é aquela que porta a verdade. A palavra não diz jamais toda a verdade, ela porta o recalcamento, que extorque parte da verdade. Nesse caso, a mentira implica uma negação, uma denegação - algo que é negado, mas que existe e cuja existência é afirmada pela própria denegação. Mas há outra forma de mentira, aquela que nega não apenas pela própria divisão inerente à palavra, mas aquela que nega que algo exista. As consequências de ambas mentiras são diferentes.

Quando um político desvia verbas polpudas que eram destinadas à saúde e à educação, isso não deveria ser considerado um crime hediondo, uma vez que tal ato acarretará em prejuízos graves - e até mesmo a morte - para milhares de pessoas? Mas a punição que se vê em tais casos é, no máximo, a perda do mandato. No caso de juízes malfeitores, figuras que no Brasil parecem ter se tornado mais numerosas do que se poderia esperar de alguém que ocupa esta função na sociedade, a punição é a aposentadoria compulsória!

Para dar exemplos desta semana: uma desembargadora de Santa Catarina ficou indignada, e gritou aos berros: "- Você sabe com quem está falando?", ao ser pega na blitz por documentação irregular e tentando evitar que o carro fosse levado para o depósito. O policial redarguiu: "- Se a senhora é magistrada, deveria dar exemplo!" Mas seu carro não foi levado como todos os outros são. O secretário nacional de Justiça, acusado de envolvimento com o ex-chefe da máfia chinesa no Brasil, é protegido pelo governo por medo de revelações comprometedoras. 
Militares que cometem crimes recebem como punição a exoneração, às vezes nem isso. Exemplo dramático: policiais que em outubro de 2009 viram o assalto e a morte de Evandro João Silva, coordenador do AfroReggae, que não só não socorreram a vítima que agonizava no chão de uma agência bancária 24 horas, como ainda ficaram com a jaqueta e o par de tênis frutos do roubo e liberaram os criminosos, estão aguardando o término da investigação exercendo funções administrativas e trabalhos internos burocráticos. E assim caminha a desumanidade.

\section{5: Cultura e ArRogÂnCIA dA FANTASIA}

Cada cultura é a entronização de algumas fantasias e o recalque de outras, ou, dito de outro modo, do acolhimento de certas formas de gozo e do rechaço de outras. A maneira pela qual as fantasias são entronizadas inconscientemente sempre traz para cada cultura uma posição de rechaço - maior ou menor, na dependência da maneira pela qual a fantasia do outro é atingida - em relação às outras.

Isso é efeito da fantasia, que localiza formas de gozo e, ao fazê-lo, pode levar a isolar todas as formas de gozo que não são compatíveis com ela. Os efeitos no campo da sexualidade são evidentes - desde a discriminação das manifestações plurais, relativas à diversidade sexual, até perseguições e mortes - mas não se restringem a eles. Assim como Freud dá à sexualidade na vida de um sujeito um alcance muito maior do que aquele que se refere exclusivamente às práticas sexuais propriamente ditas e se alastra por diferentes dimensões nas quais o sexual ressoa continuamente, no campo da cultura as coisas não poderiam ser de outro modo.

Se há uma arrogância inerente à assunção da posição fantasística de cada sujeito, na cultura há igualmente uma arrogância que, em maior ou menor grau, implica o desconhecimento e a negação de tudo aquilo que se opõe a ela - e às vezes de modo assassino.

O ataque ao escritório do magazine Charlie Hebdo em 7 de janeiro de 2015 abriu o ano novo com o mais cruel terror. Com o saldo de 12 pessoas mortas e 5 feridas gravemente, grandes artistas consagrados pelo público, esse episódio inacreditável revelou que tanto a cultura francesa quanto a cultura árabe são inimigas no inconsciente e que a pacificação não será possível na medida em que as fantasias que ambas entronizam são nitidamente avessas a tudo o que se mostre francamente opositivo a elas. Os árabes não toleram a mínima brincadeira com seus mitos 
sagrados. Os franceses não toleram que as piadas, de qualquer tipo que sejam - até as do mais negro humor - não sejam toleradas.

A arrogância é um efeito virulento do narcisismo.

\section{5: O IrReVersível DA Morte}

Tristíssima a execução em 2015 dos brasileiros Marco Archer Cardoso Moreira, carioca de 53 anos, e Rodrigo Muxfeldt Gularte, paranaense de 42 anos, na Indonésia por tráfico de drogas. Ela nos leva a pensar porque somos contra a pena de morte.

Os cientistas ensinam que a morte é inerente à vida: não há vida sem morte, até mesmo as estrelas morrem - depois de bilhões de anos de existência, mas morrem. Ensinam também que a vida humana é o produto de uma longuíssima evolução através da qual primeiro nos erguemos sobre as duas patas traseiras e, liberando as dianteiras, permitimos que surgisse muito lentamente ao longo de milhares de anos as mãos, a linguagem, a comunicação e a tecnologia.

Se o advento da vida é uma ocorrência absolutamente espantosa (vide a encarniçada busca de planetas com "condições para que haja vida" que se arrasta há décadas sem resultado), a morte é igualmente surpreendente por nos revelar através da efemeridade, maior ou menor, inerente a toda vida - que não há vida eterna. Assim, fundamentalmente transitória, a vida inclui nela mesma o imponderável de sua duração e - mais terrível - a irreversibilidade de seu encerramento.

A morte é irreversível e nisso ela contraria aquilo que constitui a essência da vida humana - a linguagem -, pois a característica principal da linguagem humana (que em psicanálise denominamos de simbólico) é sua reversibilidade. Podemos dizer uma coisa hoje e o oposto amanhã. E no terceiro dia, voltarmos à posição inicial ou acrescentarmos uma terceira ideia que se oponha às duas anteriores. O simbólico implica uma reversibilidade que é fonte de criação, de renovação e de mudança. $O$ ser humano é por isso mesmo eminentemente paradoxal, contraditório e conflituoso. Sua estrutura se baseia na diferença radical e ineliminável.

O simbólico permite ao ser humano a convivência pacífica, os acordos pessoais e os tratados entre as nações: o simbólico é salutar, ele mediatiza os encontros do sujeito com seus semelhantes e a relação dele com o mundo à sua volta. Executar um homem é arrogar-se o direito de decidir sua hora da morte, e é também destruir de modo inaceitável a reversibilidade simbólica que governa as vidas humanas e os povos: todos nós podemos mudar, voltar atrás, repensar nossas ideias 
e decisões. Sem isso, não seríamos diferentes dos animais que vivem uma vida regida apenas pelas leis biológicas que fazem de seu ciclo vital algo previsto e inarredável.

No desespero, Clarisse Gularte, mãe de Rodrigo, diagnosticado com esquizofrenia, comentou apelando para o poder do simbólico: "Mas eu acho que todo mundo tem chances. Tem que ter uma segunda chance!". Sua fala reivindica a lei da reversibilidade simbólica. Já Rodrigo, mesmo esquizofrênico, não conseguiu aceitar que essa lei não fosse preservada e manteve a esperança até o fim: "Alguém vai me tirar daqui, eu sei que eu vou sair... Meus familiares vão me retirar daqui". Marco Archer ficou preso dez anos aguardando o perdão em vão. Ele teria pedido a um guarda da prisão para matá-lo. Ele certamente passou todos esses anos sob a angústia da execução por vir e morreu em vida muitas vezes. Uma vida que aguarda a morte todos os dias está mais próxima da morte do que da vida.

A pena de morte reduz a vida humana à vida biológica, mas ela é muito mais do que isso. A obra dos grandes pensadores e criadores - por isso mesmo chamados de imortais - contraria a irreversibilidade da morte precisamente por fazer valer a potência da linguagem simbólica para afirmar o homem. Lúcido, Salvador Dali enunciou isso com precisão ao fazer com que se escrevesse em seu próprio epitáfio: "Dali está morto, mas não todo...". Por isso também esses homens executados barbaramente não estarão jamais totalmente mortos em nossa memória.

\section{7: VALOR Estético e Convivialidade Urbana}

O prefeito João Doria errou ao não ter conversado com os artistas e avaliado a receptividade dos grafites na 25 de março e nos Arcos do Jânio, em São Paulo. Mas não se pode aprender com o erro dele e colocar questões importantes para o debate?

Uma discussão que ninguém quer fazer é sobre o valor estético dos grafites. Se o espaço é público, como os grafiteiros alegam para justificar sua arte, também é uma imposição à população circulante a visão diária dos grafites. Por que a arte de uns deve se impor ao olhar de todos?

Uma cidade como São Paulo é uma cidade na qual a saturação e o excesso são regra: excesso de pessoas, de veículos, de prédios, de sons, de poluição saturam os sentidos das pessoas continuamente. Talvez seja uma observação estética simples e inegável que os grafites em geral são também formas de saturação artística: 


\title{
Cronologia Do Horror
}

excesso de cores e de formas nos desenhos que se alinham, um após o outro, saturando o olhar do transeunte. Com eles, o olhar não encontra descanso.

Se a função do quadro é a de atrair o olhar e permitir ao espectador preencher o vazio com uma forma de algum modo atraente, todos sabemos que os museus constituem frequentemente espaços em que o excesso de obras também é capaz de saturar o espectador. O excesso neutraliza a apreciação do valor estético e o vazio se revela absolutamente necessário para apreciar as formas. Mas ao museu o sujeito vai quando quer e talvez se estivéssemos continuamente postados diante das mais belas obras de arte dos museus elas também revelassem uma função de saturação insuportável. Ou melhor: elas perdessem seu caráter impactante de obra de arte.

Será que a convivialidade urbana não deve entrar na conta das conversas entre Doria, os grafiteiros e a população? Nas discussões até agora só se fala em termos sociais: respeito ao artista, diálogo com os grafiteiros etc. Mas se a arte está exposta na rua, trata-se também de avaliar o que e como algo está sendo exposto.

A alegação de que o grafite é cor e arte não justifica a invasão do olhar do público com uma pletora de cores e formas. Quanto a essas, é difícil estabelecer seu valor estético, porque a arte e a criação não devem ser julgadas em função de apreciações que dizem respeito ao conforto, à beleza, ao prazer etc. Pois a grande arte pode ser feia, desagradável e desprazerosa, e por isso mesmo constituir uma expressão artística única, singular. A arte não se mede pelo caráter decorativo de uma imagem, mas pela condensação que ela é capaz de fazer dos mais diversos elementos que regem, na maioria das vezes de forma imponderável e inconsciente, a criação humana.

O melhor de tudo foi a ironia criativa dos foliões que fizeram marchinhas carnavalescas para gozar o Doria:

\begin{abstract}
"Você pode pichar primeiro /Não deixo mole e pinto atrás/ Eu quero ver se eu pinto inteiro/ Um muro de Moema até o Brás/ Pra cidade ficar mais top/ $\mathrm{Na} 23$ e na Faria Lima/ De fantasia pra dar mais ibope/ Poso pra foto e pinto por cima/ Pinto da fonte/ Pinto no muro/ Pinto de branco/ Ou pinto mais escuro/ Pinto de fora/ E pinto dentro/ Pinto na Mooca e depois pinto no centro/ Eu te faço um convite/ Esqueça essa bobagem de grafite/ Esse muro fica muito mais bonito/ Com um quadro de Romero Britto"
\end{abstract}

\section{8: JUSTIÇA?}

As crianças têm a especial capacidade de perceber e dizer certas coisas que surpreendem os adultos. Embora não conhecesse a parábola chinesa segundo a qual 
um homem disse para o outro "Por que você está tão aborrecido comigo, se eu não Ihe dei nada?", um menino de 6 anos disse outro dia para sua mãe, no meio de grande mal-estar familiar: " - O bem faz mal para o mal”. Há uma nítida clarividência na criança pequena que se apoia evidentemente na ausência de riscos que ela corre ao pronunciar em alto e bom som: "O rei está nu!".

Para a psicanálise, os adultos mais criativos e perspicazes são aqueles que conseguem manter esse frescor mental da criança. Para descobrir tudo o que descobriu, Freud certamente precisou preservar aquela curiosidade infantil aguda que leva às grandes descobertas. Ele mesmo manifestou mais de uma vez seu espanto ao comparar a mente de uma criança com a do adulto que ela se torna depois: onde estão a vivacidade e a curiosidade que constituíam sua capacidade de questionar continuamente, perguntava-se ele. O grande psicanalista francês Jacques Lacan também confessou certa vez que tinha uma cabeça de criança de seis anos de idade.

Num esforço de imaginação podemos supor o que diria uma criança desse tipo diante da situação que o Brasil vive com a descoberta das gigantescas redes de corrupção articuladas entre políticos e empresários. Ela se perguntaria como será o julgamento desses sujeitos e por que crimes eles serão punidos. Talvez ela colocasse no primeiríssimo plano da punição pela roubalheira generalizada das finanças públicas os efeitos irreversíveis que ela produziu na população.

Ela se perguntaria: quantas pessoas morreram ou adoeceram gravemente por falta de alimento ou cuidados médicos? Quantas mulheres e homens tiveram suas vidas destruídas por terem perdido parentes na terrível violência sem limite instaurada nas comunidades mais pobres e nas grandes cidades? Quantas crianças e adolescentes tiveram as perspectivas de vida reduzidas a zero e ceifadas cedo devido a nenhuma educação recebida e à grande desorganização familiar na qual foram criadas? Qual será a punição para tanta destruição causada pela ganância e pelo absoluto descaso do poder público com os cidadãos que deveriam ser por ele protegidos? O que fará justiça a tantas mortes e a tanto desamparo, causado numa população indefesa e manipulada da forma mais perversa?

Tais criminosos, agora revelados sistematicamente, serão punidos por homicídio culposo ou doloso, ela ousaria colocar claramente a pergunta, embora sem saber o que responder. Ela indagaria, enfim: "O que poderá fazer justiça nesses casos?" 


\section{9: MORTE E DESAPARECIMENTO}

Sempre me surpreendeu muito o fato de que na língua francesa o termo desaparecer é utilizado para falar da morte. Nos livros franceses, pode-se ler com frequência nos dados do autor, referindo-se à data de sua morte: disparu en, desaparecido em...

Quando prestamos atenção a ela, a língua sempre nos ensina. Sim! É claro que a morte é uma forma de desaparecimento, pois a presença de alguém que estava ali, bem diante de nós - com sua voz, seu olhar, seus gestos, suas palavras - a partir do instante da morte não pode mais ser compartilhada. São muitas coisas que desaparecem quando a morte de alguém chega. Com ela, nunca mais haverá aperto de mãos, troca de olhares, abraços.

Não é à toa que, quando nos rebelamos contra ele, o desaparecimento imposto pela morte pode até trazer consigo a aparição fantasmática do morto. E com essa lição da língua acabamos por nos convencer de que, no fundo, o horror da morte parece residir mesmo na irreversibilidade desse desaparecimento, o que justifica a metáfora da língua francesa.

Mas, paradoxalmente, com a morte surge a presença inarredável daquela ausência, que convoca nos vivos a imensa trama de recordações. A morte de uma pessoa amada nos retira do presente e nos lança abruptamente no abismo do passado, numa queda sem fim e sem rede de proteção. Há uma certa abolição do tempo, pois nos sentimos imediatamente sem futuro: como viver sem ela? Que sentido terá a vida agora? A luz que o mundo sempre irradiou através de sua presença subitamente se apagou.

A única forma de evitar que essa morte também nos destrua é o paraquedas nomeado por Sigmund Freud de trabalho do luto, a elaboração da perda do ente querido, feita através da revisitação do passado. Recorremos assim às memórias guardadas em nosso mundo interno, que ninguém tem o poder de roubar, e mantemos a pessoa viva, pelo menos dentro de nós. Não à toa, para os egípcios antigos uma pessoa só morre quando deixam de pronunciar seu nome.

Jorge Luis Borges disse certa vez que o que ele mais aspirava com sua obra era atingir esse lugar único que é a memória do leitor. Jean-Paul Sartre também criou em Huis clos uma cena teatral para mostrar que, enquanto alguém se lembra deles, os mortos permanecem vivos. 
Por outro lado, não há como negar que existe uma diferença entre a morte e o desaparecimento. Quando alguém morre subitamente num acidente (ou num suicídio) ou após um longo período de enfermidade, os efeitos da morte sobre os vivos são diferentes. No primeiro caso, o desaparecimento decorrente da morte produz todo o impacto traumático de que ela é capaz. A morte súbita mostra o poder da morte como nenhuma outra.

Já a morte por adoecimento é uma morte acompanhada passo a passo pelos entes queridos e, por isso mesmo, não é uma morte em que o morto morre só. Tratase aqui de um desaparecimento feito de mãos dadas com o outro, em que o amor amortece até o fim o niilismo que se insinua sorrateiramente. Para quem morre e para quem fica vivo, a pior coisa que pode acontecer é alguém morrer desprovido da "redenção trazida pela presença significativa do outro", para lembrar a bela formulação de Walter Salles ao falar sobre a relação entre a mulher Dora e o menino Josué, numa entrevista sobre o filme Central do Brasil.

Há também, infelizmente rara, a única forma bela da morte, chamada por um nome que induz que se a aceite - a morte natural -, em que a vida parece quase conseguir vencer a morte ao ser vivida até o fim e não ser interrompida por nada.

Mas quando o desaparecimento é desaparecimento mesmo, isto é, não é o efeito imediatamente visível da morte - pois além do sujeito falante desaparecer, desaparece também seu corpo -, a dor que surge é inominável e não encontra onde se agarrar na queda vertiginosa no abismo, do qual jorra uma avalanche de perguntas inteiramente sem respostas.

Sem o corpo, não é possível realizar o ritual de enterramento, o mais significativo símbolo da cultura humana - onipresente em todos os povos desde a préhistória -, que não pode admitir que se trate seus mortos como uma carniça lançada a céu aberto. Não há o momento do mais verdadeiro choro - o do adeus -, o último beijo na testa, a carícia na pálpebra fechada que vela para sempre a janela do mundo do ente querido.

As declarações ferozes vindas do lugar mais elevado da República Brasileira sobre o trágico desaparecimento de Fernando Augusto de Santa Cruz Oliveira, em 23 de fevereiro de 1974, aos 24 anos de idade - uma das centenas de vítimas da fúria da ditadura militar que dominou o Brasil por décadas -ofendem terrivelmente não apenas a memória da família Santa Cruz. Elas atingem a dignidade de todos nós, pois não 


\section{Cronologia Do Horror}

levam em conta nada daquilo que constitui o cerne da nossa humanidade. $O$ Presidente ironizou com sarcasmo o desaparecimento do jovem e desmentiu o relatório da Comissão Nacional da Verdade. Negando as afirmações dos documentos oficiais sobre sua morte, afirmou com um sorriso sardônico que sabia como ele morre e poderia contar a seu filho, Felipe Santa Cruz, presidente da OAB, mas que este não ia querer saber...!

Empreendendo uma guerra contra a memória semelhante à do revisionismo europeu que nega as atrocidades cometidas pelo Terceiro Reich, a insistência do Presidente em apagar a memória do assassinato do jovem estudante representa matá-lo pela segunda vez.

Como tudo aquilo que existe, somos mortais e, além disso, os únicos seres que se sabem mortais. E que, portanto, têm que travar uma luta diária com a dor causada pela morte das pessoas amadas e pela percepção dos limites de nossa própria existência.

Ocupado por uma vociferação cruel, o lugar da Presidência, que deveria ser o porta-voz de uma palavra salutar que apazigue a alma sofrida de seu povo, está nesse triste momento de nossa história inteiramente vago. 


\title{
HORROR CHRONOLOGY
}

\begin{abstract}
Horror chronology is the collection of various writings, never published before, made over the last few years from events in the world, and especially in our country. They convey the need to put words into horror when it, appearing naked and raw, tears our souls with unbearable pain.
\end{abstract}

KEYWORDS: Horror; real; trauma; anguish; pain; symbolization. 


\section{LA Chronologie D'HORREUR}

\section{RÉSUMÉ}

La chronologie d'horreur est un recueil d'écrits divers, jamais publiés auparavant, réalisés au cours des dernières années à partir d'événements mondiaux, et en particulier de notre pays. Ils traduisent le besoin de mettre les mots en horreur lorsque celui-ci, nu et raw, déchire notre âme d'une douleur insupportable.

MотS-ÉcLÉs: Horreur; réel; un traumatisme; l'angoisse; la douleur symbolisation. 
(C) 2019 Psicanálise \& Barroco em revista

http://www.seer.unirio.br/index.php/psicanalise-barroco/index revista@psicanaliseebarroco.pro.br

Programa de Pós-Graduação em Memória Social — UNIRIO

Memória, Subjetividade e Criação

www.memoriasocial.pro.br/proposta-area.php 